\title{
Dampak Penggunaan Gadget Terhadap Penurunan Ketajaman Penglihatan
}

\author{
Siprianus Abdu ${ }^{1}$, Jenita Laurensia Saranga,2 ${ }^{2}$ Venny Sulu ${ }^{3}$, Rista Wahyuni ${ }^{4}$ \\ ${ }_{1,2,3,4}$ Program Studi Ilmu Keperawatan, Sekolah Tinggi Ilmu Kesehatan Stella Maris Makassar
}

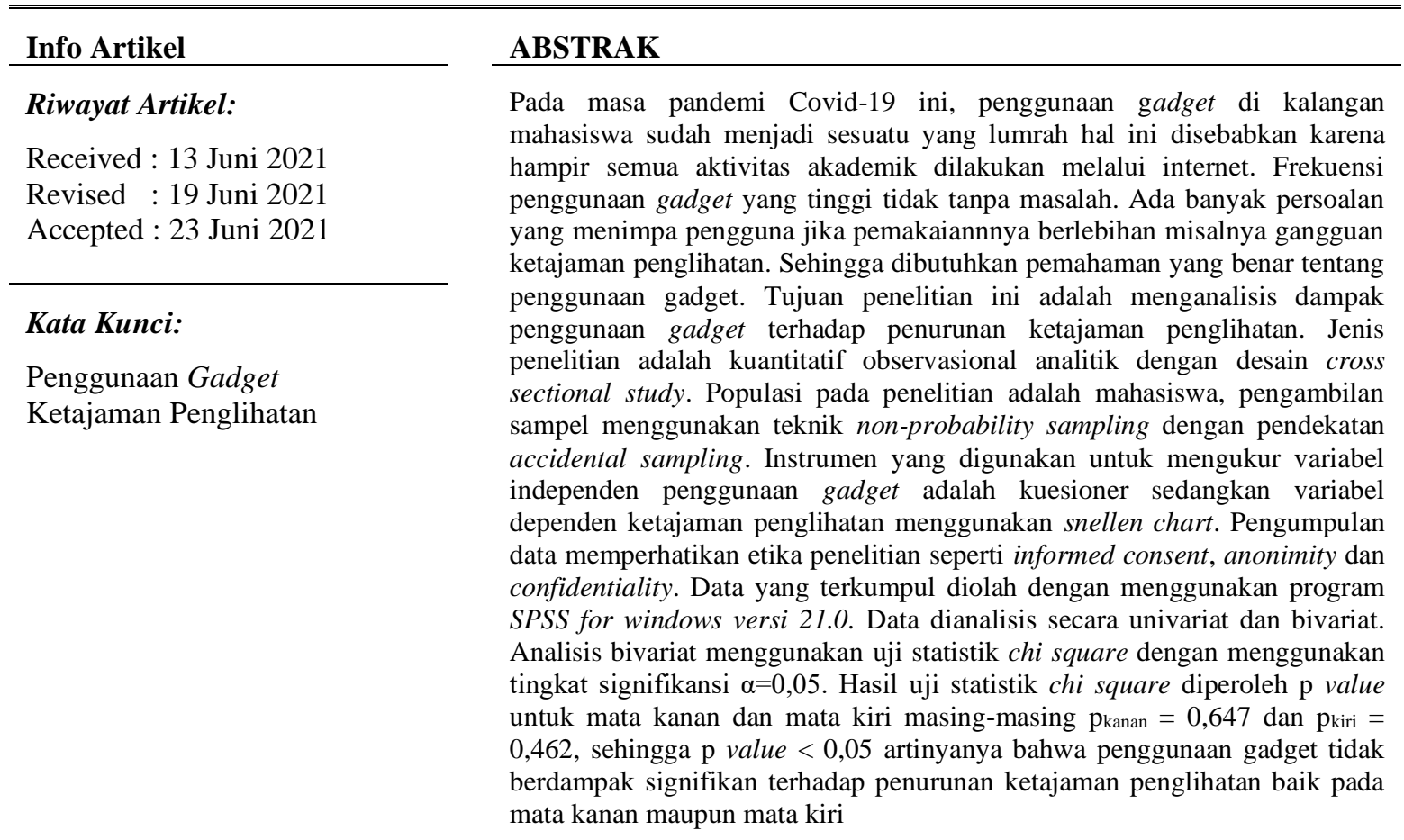

Corresponding Author:

Siprianus Abdu,

Prodi Ilmu Keperawatan, STIK Stella Maris,

Jl. Maipa No. 19, Makassar, Indonesia.

Email: siprianusabdu28@gmail.com

\section{PENDAHULUAN}

Perkembangan teknologi informasi dan komunikasi sudah semakin cepat sehingga tanpa disadari sudah mempengaruhi setiap aspek kehidupan manusia. Seiring arus globalisasi tuntutan kebutuhan pertukaran informasi yang cepat menyebabkan peranan teknologi komunikasi menjadi sangat penting. Menurut Widiawati \& Sugiman (2014), gadget merupakan barang canggih yang diciptakan dengan berbagai aplikasi yang dapat menyajikan berbagai media berita, jejaring sosial, hobi bahkan hiburan. Penggunaan gadget di kalangan pelajar dan mahasiswa masa kini merupakan sebuah keharusan untuk memilikinya, misalnya seperti handphone, tablet, laptop, dan berbagai macam gadget lainnya. Gadget dapat merubah makna suasana "kesendirian" menjadi suatu suasana yang lebih ramai dan hidup. Dengan gadget yang canggih dapat digunakan untuk mendengarkan musik, bermain games, internet, foto-foto, menonton video dan lain-lain meskipun sedang berada dalam satu ruangan sendirian tanpa ada apapun (Saleh \& Rizky, 2016). Di era globalisasi, teknologi informasi sedang berkembang sangat pesat dan membawa pengaruh besar di berbagai bidang, salah satunya pendidikan. Pendidikan sangat terbantu dengan hadirnya teknologi yang mendukung kegiatan belajar yang lebih variatif dan kreatif (Rahmawati, 2020).

Indonesia adalah negara pengguna internet terbesar di Asia Tenggara. Internet di Indonesia saat ini sudah menjadi kebutuhan primer untuk para users karena perkembangan sosial media juga salah satu faktor penting. Berdasarkan survei data Global Web Index, Indonesia adalah negara yang memiliki pengguna sosial media yang paling aktif di Asia. Indonesia memiliki 79,7\% pengguna aktif di sosial media mengalahkan 
Filipina 78\%, Malaysia 72\% dan Cina 67\%. Data statistik perkembangan internet di Indonesia mencapai 15\% atau 38.191.873 pengguna internet dari total populasi kita 251.160 .124 juta penduduk. Pengguna internet dengan menggunakan gadget mencapai 14\% dari populasi (Saleh \& Rizky, 2016).

Di Indonesia terutama anak-anak dan remaja yang golongan ekonomi menengah ke atas mempunyai angka kejadian miopia yang semakin meningkat. Salah satu faktor yang berpengaruh dalam perkembangan miopia adalah aktivitas melihat dekat (near work). Faktor risiko yang paling nyata adalah berhubungan dengan aktivitas jarak dekat, seperti membaca, menulis, menggunakan komputer dan bermain video game (Muallima et al., 2019).

Suatu sinar yang disebut High Energy Visible (HEV) atau dikenal sebagai blue light adalah salah satu bagian dari spektrum cahaya yang sangat kuat dan dihasilkan oleh peralatan elektronik modern bahkan bohlam flioresens. Cahaya ini menjadi salah satu penyebab masalah penglihatan, yaitu katarak dan agerelated macular deregenration (amd) (Puspa et al., 2018). Layar gadget menggunakan tulisan yang lebih kecil daripada sebuah buku atau cetakan hard copy lainnya sehingga jarak membaca akan lebih dekat yang meningkatkan kebutuhan penglihatan pada penggunaan yang diakibatkan muncul gejala yang termasuk dalam computer vision syndrome. Lebih dari $90 \%$ pengguna komputer mengalami gejala penglihatan seperti mata lelah, penglihatan buram, penglihatan ganda, pusing, mata kering, serta ketidaknyamanan pada okuler saat melihat dari dekat ataupun jauh setelah penggunaan komputer jangka lama (Puspa et al., 2018).

Cedera dan penyakit mata bisa mempengaruhi penglihatan. Kejernihan penglihatan disebut visus. Ketajaman penglihatan atau visus adalah kemampuan untuk membedakan bagian-bagian detail yang kecil, baik terhadap objek maupun permukaan. Penyebab gangguan penglihatan terbanyak di seluruh dunia adalah gangguan refraksi yang tidak terkoreksi, diikuti oleh katarak dan glaukoma. Sebagaimana kita ketahui mata merupakan indra penglihatan yang dapat menangkap berkas cahaya yang dipantulkan dari sebuah benda. Jika lensa yang dilalui cahaya menjadi sangat kecil sehingga ukurannya mendekati panjang gelombang dari cahaya tersebut, maka muncullah fenomena difraksi. Produsen semakin sering memproduksi smartphone dengan layar lebih cerah. Smartphone dengan layar yang demikian bila digunakan di tempat tidur dan dalam keadaan gelap dapat menyebabkan penurunan fungsi penglihatan. Peningkatan penggunaan smartphone di era sekarang ini menimbulkan kekhawatiran tentang efek negatif radiasi sinar smartphone terhadap kesehatan salah satunya fungsi penglihatan (Muallima et al., 2019).

Gangguan penglihatan seperti kelainan refraksi mata merupakan gangguan mata yang sering terjadi pada seseorang. Gangguan ini terjadi ketika mata tidak dapat melihat/fokus dengan jelas pada suatu area terbuka sehingga pandangan menjadi kabur dan untuk kasus yang parah, gangguan ini dapat menjadikan visual impairment (melemahnya penglihatan). Kelainan refraksi yang umum terjadi antara lain miopia (rabun jauh), hipermetropia (rabun dekat), dan astigmatisme. Selain itu, gangguan presbiopia kadang juga dimasukkan ke dalam golongan kelainan refraksi (WHO, 2009). Menurut laporan WHO (2012), sekitar 285 juta penduduk dunia mengalami gangguan penglihatan dimana 39 juta diantaranya mengalami kebutaan dan 246 juta penduduk mengalami penurunan penglihatan (low vision), 90\% kejadian gangguan penglihatan terjadi di negara berkembang. Secara umum penyebab kelainan refraksi yang tidak dapat dikoreksi (rabun jauh, rabun dekat, dan astigmatisme) merupakan penyebab utama gangguan penglihatan, sedangkan katarak merupakan penyebab utama kebutaan. Penyebab gangguan penglihatan terbayak di seluruh dunia adalah gangguan refraksi yang tidak terkoreksi $(48,99 \%)$, diikuti oleh $(25,81 \%)$ dan Age Related Macular Degeneration $(4,1 \%)$. Sedangkan penyebab kebutaan terbanyak adalah katarak $(34,47 \%)$, diikuti oleh gangguan refraksi yang tidak terkoreksi $(20,26 \%)$ dan glaucoma $(8,30 \%)$. Lebih dari $75 \%$ gangguan penglihatan merupakan gangguan penglihatan yang dapat dicegah. Prevalensi severe low vision pada usia produktif (15-54 tahun) sebesar 1,49\% dan prevalensi kebutaan sebesar 0,5\% (Kemenkes RI, 2018).

Pada saat survey awal beberapa mahasiswa menyampaikan testimoni tentang kondisi penglihatan, bahwa mereka merasa ada penurunan ketajaman penglihatan mata. Mahasiswa menduga bahwa penurunan ketajaman penglihatan salah satu sebabnya adalah penggunaan gadget. Sehingga itulah alasan peneliti melakukan penelitian dengan judul: dampak penggunaan gadget terhadap penurunan ketajaman penglihatan, yang tujuannya adalah menganalsis dampak penggunaan gadget terhadap penurunan ketajaman penglihatan pada mahasiswa.

\section{METODE PENELITIAN}

Jenis penelitian ini adalah kuantitatif observasional analitik dengan rancangan penelitian menggunakan metode cross sectional study yaitu rancangan penelitian dengan melakukan pengamatan variabel independen dan dependen pada waktu yang bersamaan. Penelitian ini dilakukan di Sekolah Tinggi Ilmu Kesehatan Stella Maris Makassar, pada bulan Februari sampai Maret 2021. Populasi pada penelitian ini semua mahasiswa STIK Stella Maris Makassar. Pengambilan sampel dalam penelitian ini menggunakan teknik non-probability sampling dengan pendekatan accidental sampling dengan ukuran sampel 60 responden. 
Instrumen yang digunakan dalam penelitian ini berupa kuesioner. Variabel independen penggunaan gadget telah melalui uji validitas dan uji reliabilitas dengan jumlah item 12 pertanyaan. Variabel dependen ketajaman penglihatan dengan menggunakan pengukuran snellen chart. Dalam hal pengumpulan data penelitian juga mengedepankan etika penelitian seperti informed consent, anonimity dan confidentiality. Jenis data yang dikumpulkan adalah data primer, data sekunder dan data tersier.

Pengolahan data dilakukan dengan menggunakan program SPSS for windows versi 21.0 yang diawali dengan editing, coding, processing dan cleaning. Selanjutnya data dianalisis secara univariat dan bivariat. Analisis univariat digunakan untuk mengetahui distribusi frekuensi dan persentase dari setiap variabel yang diteliti, sedangkan analisis bivariat digunakan untuk mengetahui dampak penggunaan gadget terhadap penurunan ketajaman penglihatan. Analisis bivariat menggunakan uji statistik chi square dengan menggunakan tingkat signifikansi $\alpha=0,05$ dengan interpretasi (1) jika nilai $\mathrm{p}<\alpha$ artinya ada dampak yang signifikan penggunaan gadget terhadap penurunan ketajaman penglihatan, (2) jika nilai $\mathrm{p} \geq \alpha$ artinya tidak ada dampak yang signifikan penggunaan gadget terhadap penurunan ketajaman penglihatan.

\section{HASIL}

\subsection{Karakteristik Demografi Responden}

Table 1. Distribusi Frekuensi Responden Berdasarkan Kelompok Umur

\begin{tabular}{ccc}
\hline Umur (Tahun) & Frekuensi (f) & Persentase (\%) \\
\hline $17-20$ & 17 & 28,3 \\
$21-24$ & 43 & 71,7 \\
\hline Total & 60 & 100 \\
\hline
\end{tabular}

Tabel 1 di atas memperlihatkan bahwa dari 60 responden yang diteliti karakteristik umur dominan berada pada kelompok 21-24 tahun sebanyak 43(71,7\%) responden dan paling sedikit berada pada kelompok 17-20 tahun $17(28,3 \%)$ responden.

Table 2. Distribusi Frekuensi Responden Berdasarkan Jenis Kelamin

\begin{tabular}{ccc}
\hline Jenis Kelamin & Frekuensi (f) & Persentase (\%) \\
\hline Laki-laki & 7 & 11,7 \\
Perempuan & 53 & 88,3 \\
\hline Total & 60 & 100 \\
\hline
\end{tabular}

Tabel 2 di atas memperlihatkan bahwa dari 60 responden yang diteliti dominan berjenis kelamin perempuan sebanyak 53(88,3\%) responden sedangkan yang berjenis kelamin laki-laki sebanyak $7(11,7 \%)$ responden.

\subsection{Analisa Univariat}

Tabel 3. Distribusi Frekuensi Berdasarkan Penggunaan Gadget

\begin{tabular}{ccc}
\hline Penggunaan gadget & Frekuensi (f) & Persentase (\%) \\
\hline Baik & 8 & 13,3 \\
Kurang Baik & 52 & 86,7 \\
\hline Total & 60 & 100
\end{tabular}

Tabel 3 di atas memperlihatkan bahwa dari 60 responden yang diteliti variabel penggunaan gadget dominan berada pada kategori kurang baik yakni 52(86,7\%) responden dan penggunaan gadget kategori baik sebanyak $8(13,3 \%)$ responden. 
Tabel 4. Distribusi Frekuensi Berdasarkan Ketajaman Penglihatan Mata Kanan

\begin{tabular}{ccc}
\hline Ketajaman penglihatan & Frekuensi (f) & Persentase (\%) \\
\hline Normal & 27 & 45 \\
Menurun & 33 & 55 \\
\hline Total & 60 & 100 \\
\hline
\end{tabular}

Tabel 4 di atas memperlihatkan bahwa dari 60 responden yang diteliti ketajaman penglihatan mata kanan dominan berada pada kategori menurun sebanyak 33(55\%) responden dan yang masuk kategori normal sebanyak $27(45 \%)$ responden.

Tabel 5. Distribusi Frekuensi Berdasarkan Ketajaman Penglihatan Mata Kiri

\begin{tabular}{ccc}
\hline Ketajaman penglihatan & Frekuensi (f) & Persentase (\%) \\
\hline Normal & 22 & 36,7 \\
Menurun & 38 & 63,3 \\
\hline Total & 60 & 100 \\
\hline
\end{tabular}

Tabel 5 di atas memperlihatkan bahwa dari 60 responden yang diteliti ketajaman penglihatan mata kiri dominan berada pada kategori menurun sebanyak 38(63,3\%) responden dan yang masuk kategori normal sebanyak 22(36,7\%) responden.

\subsection{Analisa Bivariat}

Tabel 6. Analisa Dampak Penggunaan Gadget Terhadap Penurunan Ketajaman Penglihatan Mata Kanan

\begin{tabular}{|c|c|c|c|c|c|c|c|}
\hline \multirow{3}{*}{ Penggunaan Gadget } & \multicolumn{6}{|c|}{ Ketajaman Penglihatan Mata Kanan } & \multirow{3}{*}{ Nilai $\rho$} \\
\hline & \multicolumn{2}{|c|}{ Normal } & \multicolumn{2}{|c|}{ Menurun } & \multicolumn{2}{|c|}{ Total } & \\
\hline & $\mathrm{f}$ & $\%$ & $\mathrm{f}$ & $\%$ & f & $\%$ & \\
\hline Baik & 3 & 5 & 5 & 8,3 & 8 & 13,3 & \multirow{3}{*}{0,647} \\
\hline Kurang Baik & 24 & 40 & 28 & 46 & 52 & 86,7 & \\
\hline Total & 27 & 45 & 33 & 54,3 & 60 & 100 & \\
\hline
\end{tabular}

Tabel 6 di atas memperlihatkan tabulasi silang dari hasil uji statistik. Hasil uji statistik disimpulkan bahwa penggunaan gadget tidak berdampak signifikan terhadap penurunan ketajaman penglihatan pada mata kanan mahasiswa. Hasil ini didukung oleh sel yang menjelaskan bahwa penggunaan gadget baik ketajaman penglihatan menurun sebanyak $5(8,3 \%)$ responden dan penggunaan gadget kurang baik ketajaman penglihatan normal sebanyak 24(40\%) responden. Hasil lain dalam penelitian ini menunjukkan bahwa penggunaan gadget baik ketajaman penglihatan normal sebanyak 3(5\%) responden serta penggunaan gadget kurang baik ketajaman penglihatan menurun sebanyak 28(46\%) responden.

Tabel 7. Analisa Dampak Penggunaan Gadget Terhadap Penurunan Ketajaman Penglihatan Mata Kiri

\begin{tabular}{|c|c|c|c|c|c|c|c|}
\hline \multirow{3}{*}{ Penggunaan Gadget } & \multicolumn{6}{|c|}{ Ketajaman Penglihatan Mata Kiri } & \multirow{2}{*}{ Nilai $\rho$} \\
\hline & \multicolumn{2}{|c|}{ Normal } & \multicolumn{2}{|c|}{ Menurun } & \multicolumn{2}{|c|}{ Total } & \\
\hline & $f$ & $\%$ & $\mathrm{f}$ & $\%$ & $\mathrm{f}$ & $\%$ & \\
\hline Baik & 2 & 3,3 & 6 & 10 & 8 & 13,3 & 0,462 \\
\hline Kurang Baik & 20 & 33,3 & 32 & 53,3 & 52 & 86,7 & \\
\hline Total & 22 & 36,3 & 38 & 63,3 & 60 & 100 & \\
\hline
\end{tabular}

Tabel 7 di atas memperlihatkan tabulasi silang dari hasil uji statistik. Hasil uji statistik disimpulkan bahwa penggunaan gadget tidak berdampak signifikan terhadap penurunan ketajaman penglihatan pada mata kiri mahasiswa. Hasil ini didukung oleh sel yang menjelaskan bahwa penggunaan gadget baik dengan ketajaman penglihatan kategori menurun sebanyak 6 (10\%) responden dan penggunaan gadget kurang baik 
dengan ketajaman penglihatan kategori normal sebanyak $20(33,3 \%)$ responden. Hasil lain dalam penelitian ini menunjukkan penggunaan gadget kategori baik dengan ketajaman penglihatan normal sebanyak $2(3,3 \%)$ responden, sedangkan penggunaan gadget kategori kurang baik dengan ketajaman penglihatan menurun sebanyak $32(53,3 \%)$ responden.

\section{DISKUSI}

Hasil penelitian ini adalah penggunaan gadget tidak berdampak signifikan terhadap penurunan ketajaman penglihatan pada mata kanan maupun mata kiri. Hal ini didukung oleh p value dan nilai sel pada tabel tabulasi silang baik pada mata kanan maupun mata kiri, yang menjelaskan bahwa penggunaan gadget baik tetapi ketajaman penglihatan menurun dan sebaliknya penggunaan gadget kurang baik tetapi ketajaman penglihatan normal. Hasil ini sejalan dengan penelitian yang dilakukan oleh Panambunan et al (2019), tidak terdapat hubungan antara penggunaan smartphone dengan ketajaman penglihatan dan juga tidak terdapat hubungan antara intensitas penggunaan smartphone dengan ketajaman penglihatan. Adapun penelitian lain yang mendukung penelitian ini yaitu dari Ernawati (2015), yang menunjukkan tidak ada pengaruh antara durasi lamanya menggunakan gadget terhadap penurunan tajam penglihatan.

Menurut Hidayani et al (2020), tidak ada hubungan jarak pandang saat menggunakan gadget dengan ketajaman penglihatan hal ini dikarenakan saat mata melihat objek maka akan terjadi akomodasi baik pada jarak dekat maupun jarak jauh, kegiatan akomodasi yang dilakukan otot mata ini dapat mengakibatkan kelelahan mata. Kejadian ini dapat terjadi sebagai akibat tidak efektifnya akomodasi hasil dari otot mata yang melemah dan tidak stabil. Posisi menggunakan gadget yang salah dapat menimbulkan sakit kepala serta nyeri pada leher. Nyeri yang terjadi diakibatkan posisi leher yang salah dan tegang karena seringnya melihat layar gadget, sakit kepala yang dialami dapat terjadi karena kelelahan mata akibat penggunaan mata yang terlalu lama sehingga tidak ada hubungan antara posisi tubuh saat menggunakan gadget dengan ketajaman penglihatan.

Menurut Nugraha (2018), ada beberapa keadaan yang dapat menyebabkan penurunan ketajaman penglihatan yaitu faktor penyakit, faktor genetik, faktor usia, faktor lingkungan dan aktivitas kerja dekat yang berlebihan (faktor perilaku). Hasil lain yang menjelaskan hubungan penggunaan gadget yang baik terhadap ketajaman penglihatan mata kanan normal sebanyak $3(5 \%)$ responden dan penggunaan gadget yang kurang baik ketajaman penglihatan mata kanan menurun sebanyak 28 (46\%) responden. Juga yang menjelaskan penggunaan gadget baik ketajaman penglihatan mata kiri normal sebanyak $2(3,3 \%)$ responden dan penggunaan gadget kurang baik ketajaman penglihatan mata kiri menurun sebanyak $32(53,3 \%)$ responden.

Fitri \& Suprayanto (2017), menjelaskan bahwa penyebab penurunan ketajaman penglihatan yaitu: frekuensi menggunakan gadget, melihat layar gadget dalam waktu yang lama akan memberikan dorongan pada mata serta susunan saraf. Jarak pandang terhadap gadget $<30 \mathrm{~cm}$ menyebabkan mata berakomodasi lebih berat sehingga dapat menyebabkan kelelahan mata. Intensitas cahaya yang kurang baik bisa mengakibatkan gangguan atau kelelahan mata. Posisi pada saat membaca dengan tiduran cukup berisiko karena saat menggunakan gadget dengan posisi ini akan mengakibatkan mata muda lelah. Hal ini sejalan dengan hasil penelitian Handriani (2016), yang menyatakan bahwa ada pengaruh jarak pandang saat menggunakan gadget terhadap ketajaman penglihatan.

Hasil penelitian ini tidak sejalan dengan penelitian yang dilakukan oleh Fitri \& Suprayanto (2017), yang mengatakan bahwa intensitas cahaya akan menentukan jangkauan akomodasi. Intensitas cahaya yang baik dapat mengurangi ketegangan mata dan jika pencahayaan terasa kurang maka akan meningkatkan tingkat akomodasi mata untuk melihat objek. Intensitas cahaya yang tidak baik dapat membuat mata berakomodasi lebih kuat dan jika dibiarkan akan menyebabkan penurunan ketajaman penglihatan. Hal ini didukung oleh penelitian Ernawati (2015), yang mengatakan bahwa terdapat pengaruh intensitas cahaya pada saat menggunakan gadget terhadap ketajaman penglihatan. Ketika cahaya terasa kurang bagi mata, maka proses akomodasi mata akan lebih kuat untuk melihat benda. Daya pembiasan lensa bertambah kuat akibat dari akomodasi. Ketika benda dilihat dengan jarak dekat maka proses akomodasi mata semakin kuat. Intensitas cahaya yang kurang baik dapat mengakibatkan mata berakomodasi lebih kuat dan jika dibiarkan dalam jangka waktu lama akan mengakibatkan kerusakan mata permanen.

Hasil penelitian ini menandaskan bahwa penurunan ketajaman penglihatan yang terjadi pada mahasiswa tidak disebabkan oleh penggunaan gadget tetapi kemungkinan lebih dipengaruhi oleh faktorfaktor yang secara teoritis ada seperti genetik, usia, obat-obatan yang dikonsumsi, penyakit yang dialami (diabetes melitus dan tekanan darah tinggi), radiasi, kurangnya konsumsi vitamin A dan kurangnya pencahayaan saat beraktivitas. Namun walaupun demikian mahasiswa atau pengguna gadget tetap harus memahami bahwa penggunaan gadget yang berlebihan baik dari sisi lama penggunaan, intensitas cahaya maupun cara memakainya akan berdampak terhadap ketajaman penglihatan jika berlangsung dalam waktu yang cukup lama. 


\section{KESIMPULAN}

Berdasarkan hasil penelitian dapat disimpulkan bahwa penggunaan gadget tidak berdampak signifikan terhadap penurunan ketajaman penglihatan pada mata kanan maupun mata kiri. Mahasiswa yang mengalami penurunan ketajaman penglihatan lebih disebabkan oleh multi faktor, yang secara teoritis faktor-faktor itu adalah genetik, obat-obatan yang dikonsumsi, penyakit yang dialami seperti diabetes melitus dan hipertensi, kurangnya konsumsi vitamin A dan kurangnya pencahayaan saat beraktivitas. Namun walaupun hasil penelitian seperti ini tetapi pengguna gadget tetap harus membatasi lama penggunaannya sebab jika hal tersebut berlangsung dalam waktu yang cukup lama maka tidak menutup kemungkinan kondisi akomodasi mata akan menjadi bermasalah.

\section{REFERENSI}

Dharma.KK. (2011). Metodologi Penelitian Keperawatan. Pedoman Melaksanakan dan Menerapkan Hasil Penelitian. Jakarta: Trans Info Medika.

Djua, N. (2015). Gambaran faktor-faktor yang mempengaruhi progresivitaas penderita miopia di RSUD Prof. DR. H. ALOEI SABOE. kota gorntalo.

Goldschmidt, E., \& Jacobsen, N. (2014). Genetic and environmental effects on myopia development and progression. Eye (Basingstoke), 28(2), 126-133. https://doi.org/10.1038/eye.2013.254

Grant, M. B., \& Lutty, G. A. (2012). Retinal and Choroidal Vasculature. Retinal Oxygenation. In Retina Fifth Edition (Vol.1, pp. 433-446). Elsevier Inc. https://doi.org/10.1016/B978-1-4557-07379.00018-7

Handriani, R. (2016). Pengaruh Unsafe Action Penggunaan Gadget terhadap Ketajaman Penglihatan Siswa Sekolah Dasar Islam Tunas Harapan.Universitas Dian Nuswantoro

Harfiyanto, D., Budi, U. C., \& Tjaturahono, B. (2015). Pola Interaksi Sosial Siswa Pengguna Gadget di SMAN 1 Semarang. 4(1). 2252-6390.http://journal.unnes.ac.id/sju/index.php/jess

Ilyas, S. (2008). Ilmu Penyakit Mata (edisi 3). Jakarta: Fakultas Kedokteran Universitas Indonesi.

Ilyas, S. (2009). Kelainan Refraksi dan Kacamata. Jakarta: Fakultas Kedokteran Universitas Indonesia.

Ilyas, S. (2010). Sari Ilmu Penyakit Mata. Jakarta: Fakultas Kedokteran Universitas Indonesia.

Ilyas, S. (2013). Ilmu Penyakit Mata. Jakarta: Fakultas Kedokteran Universitas Indonesia.

Irawan, J. (2013). Pengaruh Kegunaan Gadget terhadap Kemampuan Bersosialisasi pada Remaja. 8(5).

Kementrian Kesehatan RI. (2018). InfoDATIN Pusat Data Informasi Kesehatan RI. Jakarta: KEMENKES RI.

L, F., M, J., \& V., L. K. (2017). A Proinflammatory Function of toll-like Receptor 2 in the Retinal Pigmen Epithelium as A Novel Target for Reducing Choroidal Neovascularization in Age-Related Macular Degeneration. American Journal of Pathology, 10. https://doi.org/10.1016/J.AJPATH.2017.06.015

Larik Ahmed, S., Mallah Ali, G., Talpur, M., Saeed, A., Larik, F. A., Suhag, A. K., \& Karim, S. (2016). Adverse Effects of Cell Phone Radiation on Human Health. Iternational Journal of Scientific and Engineering Research, 7(10), 480-486.

Lauralee, S. (2018). Fisiologi manusia dari sel ke sistem (Edisi 6). Jakarta: EGC.

Manumpil. (2015). Hubungan Penggunaan Gadget dengan Tingkat Prestasi Siswa di SMAN 9 Manado. ejournal Keperawatan (e-Kep) $3: 1-5$.

Mescher, A. L. (2012). Histologi Dasar JUNQUEIRA Teks \& Atlas. In Histologi Dasar JUNQUEIRA Teks \& Atlas (Edisi 12., Vol. 12). Jakarta: EGC.

Muallima, N., Febriza, A., \& Putri, R. K. (2019). Hubungan Penggunaan Gadget dengan Penurunan Tajam Penglihatan pada Siswa SMP Unismuh Makassar. Jurnal Ilmiah Kesehatan, 7, 79-85.

Oliver, J., \& Cassidy, L. (2012). At a Glance Oftalmologi. Jakarta: Erlangga.

Permana, M. A., Koesyanto, H., \& Mardiana. (2015). Faktor yang Berhubungan dengan Computer Vision Syndrome (CVS) pada Pekerja Rental Komputer di Wilayah UNNES. Unnes Journal of Public Health, 4(3). https://doi.org/10.15294/ujph.v4i3.6372

Puspa, A. K., Loebis, R., \& Nuswantoro, D. (2018). Pengaruh Penggunaan Gadget terhadap Penurunan Kualitas Penglihatan Siswa Sekolah Dasar. 6(47), 28-33.

Rahmawati, Z. D. (2020). Penggunaan Media Gadget dalam Aktivitas Belajar dan Pengaruhnya terhadap Perilaku Anak. 3(1), 93.

Riordan, P., Eva, \& Whitcher, J. P. (2013). oftalmologi umum (edisi 17). Jakarta: EGC.

Rudhiati, Apriany, \& Hardianti. (2015). Hubungan Durasi Bermain Video Game dengan Ketajaman Penglihatan Anak Usia Sekolah. Jurnal Skolastik Keperawatan, 1,(2).

Saleh, \& Rizky, A. (2016). Dampak Penggunaan Gadget Terhadap Ketajaman Penglihatan Mahasiswa Fakultas Kedokteran USU. http://repositori.usu.ac.id

Saphira, E., A, W. A., \& J, J. F. (2017). Visual Acuity and Contrast Sensitivity Development in Children. Optometry and Vision Science, 94(8), 830-837. https://doi.org/10.1097/opx.0000000000001101 
Subitha, M. (2013). Pengaruh Komputer Terhadap Kesehatan Mata. Universitas Guna Dharma. Jakarta: Universitas Guna Darma.

Sumantri, \& Mohamad, S. (2015). Strategi Pembelajaran Teori dan Praktik di Tingkat Pendidikan Dasar. Jakarta: Rajawali Pers.

Syaifuddin, H. (2012). Anatomi Fisiologi: Kurikulim Berbasis Kompetensi intuk Keperawatan dan Kebidanan (edisi 4). Jakarta: EGC.

Wati, R. (2018). Akomodasi dalam Refraksi Tinjauan Pustaka. 7(Supplement 1), 13-18.

WHO. (2009). Global nitiative for the Elimination of Avoidable Blindness; action plan 2006-2011. 12, 32.

WHO. (2012). Global Data on Visual Impairment. Retrieved from http://www.who.int/blindness/GLOBALDATAFINALforweb.pdf

Widiawati, \& Sugiman. (2014). Pengaruh Penggunaan Gadget terhadap Daya Kembang Anak. Jurnal Keperawatan.

Wijanarto, J., \& Setiawati, E. (2016). Ayah Ibu Baik Parenting Era Digital. keluarga indonesia bahagia.

Winoto, H. (2013). Dampak Penyalahgunaan Teknologi Komunikasi Ponsel dan Gadget pada Anak dan Remaja. Retrieved from http://komunikasi.us/index.php/course/1789-contoh-riset-teknologi dan komunikasi. 